\title{
Faster returns on 'leaf economics' and different biogeochemical niche in invasive compared with native plant species
}

\author{
JOSEP PENUELAS*, JORDI SARDANS*, JOAN LLUSIÀ*, SUSAN M. OWEN*†, JOFRE \\ CARNICER*, THOMAS W. GIAMBELLUCA , ENRICOL. REZENDE§, MASHURI WAITE \\ and ÜLO NIINEMETS $\|$ \\ *Unitat d'Ecofisiologia i Canvi Global CSIC-CEAB-CREAF, CREAF, Facultat de Ciències, Edifici C, Universitat Autònoma de \\ Barcelona, 08913 Bellaterra, Spain, †Centre for Ecology and Hydrology Edinburgh, Penicuik, EH26 0QB Scotland, UK, \\ $\ddagger$ Department of Geography, University of Hawaii at Manoa, 2424 Maile Way, Honolulu, HI 96822, USA, §Departament de Genètica \\ $i$ de Microbiologia, Facultat de Biociències, Edifici C, Universitat Autònoma de Barcelona, 08193 Bellaterra, Spain, $\uparrow$ Department of \\ Botany, University of Hawaii at Manoa, 3190 Maile Way, Honolulu, HI 96822, USA, ||Estonian University of Life Sciences, \\ Institute of Agricultural and Environmental Sciences, Kreutzwaldi 1, Tartu 51014, Estonia
}

\begin{abstract}
Plant-invasive success is one of the most important current global changes in the biosphere. To understand which factors explain such success, we compared the foliar traits of 41 native and 47 alien-invasive plant species in Oahu Island (Hawaii), a location with a highly endemic flora that has evolved in isolation and is currently vulnerable to invasions by exotic plant species. Foliar traits, which in most cases presented significant phylogenetic signal, i.e. closely related species tended to resemble each other due to shared ancestry, separated invasive from native species. Invasive species had lower leaf mass per area and enhanced capacities in terms of productivity (photosynthetic capacity) and nutrient capture both of macro- (N, P, K) and microelements ( $\mathrm{Fe}, \mathrm{Ni}, \mathrm{Cu}$ and $\mathrm{Zn}$ ). All these differences remain highly significant after removing the effects of phylogenetic history. Alien-invasive species did not show higher efficiency at using limiting nutrient resources, but they got faster leaf economics returns and occupied a different biogeochemical niche, which helps to explain the success of invasive plants and suggests that potential increases in soil nutrient availability might favor further invasive plant success.
\end{abstract}

Keywords: biogeochemical niche, Hawaiian flora, invasive success, leaf economics, leaf elemental composition, LMA, nutrient stoichiometry, photosynthetic capacity

Received 1 July 2009 and accepted 6 August 2009

\section{Introduction}

Plant-invasive success is one of the most important current global changes in the biosphere (Mooney \& Hobbs, 2000). To understand which factors explain such success, many studies have compared the relative performance of co-occurring native and alien-invasive plants. Although relative performance often depends on growth conditions, invaders are more likely to have higher leaf area and lower tissue construction costs to increase productivity, and greater phenotypic plasticity which is advantageous in disturbed environments

Correspondence: Josep Penuelas, CREAF, Facultat de Ciències, Universitat Autònoma de Barcelona, 08913 Bellaterra, Catalonia, Spain, tel. + 9358113 12, fax + 9358141 51, e-mail:

josep.penuelas@uab.cat
(Daehler et al., 2004). Foliar traits such as higher photosynthetic capacity per dry mass $\left(A_{\text {mass }}\right)$ and lower leaf construction costs associated with a lower leaf mass per area (LMA) partly explain the success of alien plant species (Baruch \& Goldstein, 1999; Funk \& Vitousek, 2007), since they may contribute to faster growth rates for invaders and confer a competitive advantage over native species (Reich et al., 1997). In a recent study, Wright et al. (2004) have described coordinated change in leaf structure/function relationships known as the 'leaf economics spectrum,' running from a slow return end encompassing species with high LMA, longevity and low nutrient content and $A_{\text {mass, }}$ to a fast-return end with the opposite suite of traits. It is possible that alieninvasive and native species have contrasting suites of foliar traits, placing native plants in the slow return end of the spectrum and invasive aliens in the fast return end. 
Another possible driving factor for the success of invasive plant species is their greater nutrient capture capacity relative to native species and the resulting effects on nutrient cycle. In a review of 79 studies containing data of 56 alien plant species in different environmental situations, Ehrenfeld (2003) concluded that invasive species frequently increase nitrogen $(\mathrm{N})$ availability, alter $\mathrm{N}$ fixation rates, and produce litter with higher decomposition rates than co-occurring natives. Other experiments have shown that invasive plants accumulate more $\mathrm{N}$ and/or phosphorus $(\mathrm{P})$ than the co-occurring natives (Ashton et al., 2005; Dassonville et al., 2007) and that increases of nutrient availability by fertilization or atmospheric deposition have favored the expansion of invasive plants (Niinemets et al., 2003; Siemann \& Rogers, 2007). On the other hand, several studies could not establish any clear relation between nutrient availability and alien plant expansion (Witkowski, 1994; Dassonville et al., 2008) or, in some instances, have reported the opposite trends (Holmgren et al., 2000; Brewer \& Cralle, 2003). Further studies are thus needed to better clarify the role of $\mathrm{N}$ and $\mathrm{P}$ economy in plantinvasive success, as well as the potential role of other elements such as $\mathrm{K}, \mathrm{Mg}, \mathrm{Ca}, \mathrm{Mo}, \mathrm{Mn}, \mathrm{Fe}, \mathrm{S}$ and trace elements such as As or $\mathrm{Cd}$, which has received considerably less attention in the plant invasion literature.

Tropical island ecosystems appear to be especially vulnerable to invasive species and provide an ideal scenario to study which factors underlie plant-invasive success. For example, the Hawaiian Islands constitute the most isolated terrestrial ecosystem of the Earth (Vitousek \& Walker, 1989) and seem to be particularly vulnerable to invasions by nonindigenous species (Hughes \& Denslow, 2005; Hughes \& Uowolo, 2006). A great number of flowering plant species, 861, representing the $47 \%$ of total Hawaiian angiosperm flora, are naturalized alien species (Wagner et al., 1999), and approximately $25 \%$ of Hawaiian native flora, $90 \%$ of which is endemic, has been listed as threatened or endangered. The climatic and soil geography of these islands may also provide important insights on the mechanisms behind plant invasions. There is a dramatic altitudinal gradient in environmental conditions and strong climatic differences between leeward and windward sides of the islands (Müller-Dombois \& Fosberg, 1998), and nutrient cycling and availability tend to decrease at higher altitudes (Scowcroft et al., 2000; Schuur \& Matson, 2001). These gradients might be associated with the continuous increase of elevation range of invasive species during the colonization of these islands, 'pushing' native species to higher, nutrient-poorer and climatically harsher environments (Daehler et al., 2004). However, conclusive evidence in this context is currently lacking.
Here, we studied the association between the plantinvasive success in the Oahu (Hawaii) flora and species' foliar economics and elemental composition. We screened 41 native and 47 alien plant species from different climate conditions and taxonomic groups and, after having quantified and removed the effects of phylogenetic history, we compared the photosynthetic capacity $\left(A_{\text {mass }}\right)$, the LMA and the foliar concentration of different elements of alien species with those of native species. We hypothesized that invasive species present faster returns on their leaf economics, characterized by high $A_{\text {mass }}$ low LMA and high nutrient (N, P and K) concentrations (Wright et al., 2004), when compared with native species. On the same rationale, we also hypothesized that alien and native species occupy different biogeochemical niches, which is the logical prediction if alien and native species differ significantly in key physiological, structural and especially chemical foliar properties.

\section{Materials and methods}

\section{Field sites}

The collection and sampling of plants for this study was conducted in May 2007 on Oahu, the third largest of Hawaiian islands. It was formed ca. 2.6 million years ago (Guillou et al., 2000). Typical of the larger Hawaiian Islands, the climate is characterized by very steep rainfall gradients over short distances (Müller-Dombois \& Fosberg, 1998). Lowlands on the leeward side have a pronounced dry summer season, while precipitation is distributed almost uniformly in the lowlands of the windward side and in mountainous rain forests. Owing to the oceanic tropical climate, temperature oscillations are small with winters having on average $2-3{ }^{\circ} \mathrm{C}$ cooler temperatures than summers. As large differences in composition of native and alien vegetation occur in response to rainfall gradients, four sites with distinct precipitation regimes were selected for plant sampling in the leeward lowlands of Oahu and in the leeward side of Koolau mountains (Table 1). We conducted a representative selection of dry to wet environments starting from lowlands (dry, species poor) and ending up with wet trails in tropical rainforest (Tantalus) and cloud forest (Wiliwilinui).

St Louis Heights-Waahila Ridge (from $21^{\circ} 17^{\prime} 42.82^{\prime \prime} \mathrm{N}$, $157^{\circ} 48^{\prime} 44.18^{\prime \prime} \mathrm{W}$, elevation $39 \mathrm{~m}$, to $21^{\circ} 18^{\prime} 7.06^{\prime \prime} \mathrm{N}$, $157^{\circ} 48^{\prime} 31.49^{\prime \prime} \mathrm{W}$, elevation $272 \mathrm{~m}$ ) supports dry open semideciduous forest dominated by alien species Agave americana, Leucaena leucocephala, Haematoxylum campechianum and Casuarina equisetifolia, with scattered native species Osteomeles anthyllidifolia, Psydrax odorata and Waltheria indica (Table 1). The soils are well-drained 
Table 1 Description of the study sites

\begin{tabular}{|c|c|c|c|c|c|c|c|c|c|}
\hline \multirow[b]{2}{*}{ Site } & \multirow[b]{2}{*}{ Coordinates } & \multirow{2}{*}{$\begin{array}{l}\text { Average } \pm \mathrm{SD}^{*} \\
\text { altitude }(\mathrm{m})\end{array}$} & \multicolumn{2}{|c|}{$\begin{array}{l}\text { Average } \pm \text { SD precipitation } \\
(\mathrm{mm})\end{array}$} & \multicolumn{5}{|c|}{$\begin{array}{l}\text { Average } \pm \text { SD annual temperature } \\
\left({ }^{\circ} \mathrm{C}\right)\end{array}$} \\
\hline & & & Annual & 3 driest months & Minimum & Maximum & $n$ & $N$ & $A$ \\
\hline St Louis Heights & $21^{\circ} 18^{\prime} \mathrm{N}, 157^{\circ} 48^{\prime} \mathrm{W}$ & $171 \pm 65$ & $1430 \pm 210$ & $197 \pm 45$ & $18.7 \pm 0.5$ & $26.9 \pm 0.5$ & 18 & 2 & 16 \\
\hline Hahaione Valley & $21^{\circ} 19^{\prime} \mathrm{N}, 157^{\circ} 43^{\prime} \mathrm{W}$ & $390 \pm 140$ & $1268 \pm 22$ & $157 \pm 7$ & $17.1 \pm 0.6$ & $25.7 \pm 0.5$ & 16 & 3 & 13 \\
\hline Tantalus & $21^{\circ} \mathrm{N}, 20^{\prime} 157^{\circ} 49^{\prime} \mathrm{W}$ & $441 \pm 24$ & $3670 \pm 440$ & $705 \pm 41$ & $16.2 \pm 0.6$ & $24.1 \pm 0.6$ & 27 & 13 & 14 \\
\hline Wiliwilinui & $21^{\circ} 19^{\prime} \mathrm{N}, 157^{\circ} 45^{\prime} \mathrm{W}$ & $660 \pm 120$ & $2100 \pm 150$ & $413 \pm 60$ & $15.2 \pm 0.9$ & $23.8 \pm 0.8$ & 27 & 23 & 4 \\
\hline
\end{tabular}

*Averages are based on the number of species sampled and species-specific locations. In statistical analyses, exact species-specific environmental data were used. $n$, total number of species; $N$, number of native species; $A$, number of alien species.

mollisols of the Pamoa series located at lower elevations and ultisols of the Manana series at higher elevations in this site (Foote et al., 1972). Dark-reddish brown Pamoa silty clay is formed on fine-textured old alluvium, while reddish brown Manana silty clay is developed from material weathered from basic igneous rock. Pamoa silty clay is neutral in the surface layer and strongly acidic in deeper layers, whereas Manana silty clay is strongly acidic throughout the profile.

The Hahaione Valley trail (starting at the end of Hahaione street, $21^{\circ} 18^{\prime} 14.50^{\prime \prime} \mathrm{N}, 157^{\circ} 42^{\prime} 45^{\prime \prime} \mathrm{W}$, elevation $103 \mathrm{~m}$, Table 1) runs from the leeward side of Oahu to the top of Koolau crest $\left(21^{\circ} 19^{\prime} 3.63^{\prime \prime} \mathrm{N}, 157^{\circ} 43^{\prime} 7.15^{\prime \prime} \mathrm{W}\right.$, elevation $511 \mathrm{~m}$ ). The site supports dry closed forest at lower elevations and mesic forest at higher elevations. The dry semideciduous forest is dominated by alien species L. leucocephala, Schinus terebinthifolius and C. equisetifolia and native species $O$. anthyllidifolia, while the mesic forest is dominated by alien species Psidium cattleianum, P. guajava, Schefflera actinophylla and Araucaria columnaris, and by native species Metrosideros polymorpha, and Diospyrus sandwicensis. The site is characteristic of the Koolau Range mountainous areas with steep land interrupted by numerous drainage channels and V-shaped valleys with very steep slopes and narrow ridges between the valleys. Pedologically the site is classified as rock land, which consists of areas with exposed rock outcrops of basalt and andesite covering 25-90\% of the surface (Foote et al., 1972). The shallow soils between the rocks are typically dark-brown inceptisols.

The Wiliwilinui Ridge trail (starting at the end of Okoa street, $21^{\circ} 17^{\prime} 52.55^{\prime \prime} \mathrm{N}, 157^{\circ} 45^{\prime} 39.14^{\prime \prime} \mathrm{W}$, elevation $145 \mathrm{~m}$, Table 1) runs from the leeward side of Oahu up to the Koolau crest $\left(21^{\circ} 19^{\prime} 39.11^{\prime \prime} \mathrm{N}, 157^{\circ} 44^{\prime} 54.17^{\prime \prime} \mathrm{W}\right.$, elevation $778 \mathrm{~m}$ ). The trail is characterized by dry-mesic closed forest at lower elevations, mesic forest at midelevation and stunted shrubby cloud-forest at the highest elevations in Koolau Range (Müller-Dombois \& Fosberg, 1998). The vegetation in lower elevations is characterized by aliens P. cattleianum and Acacia confusa with scattered native species Santalum freycinetianum and Alyxia stellata, the mesic forest is dominated by alien P. cattleianum and by natives Acacia koa, Psychotria mariniana and M. polymorpha, while upper elevations are dominated by aliens Clidemia hirta, and Rubus rosifolius, and by native Metrosideros spp., Melicope spp. and Myrsine spp., and by dense thickets of the native fern Dicranopteris linearis (Table 2 for species). The soils at lower elevations on the V-shaped gulch ascending upwards are oxisols of Helemano series developed on alluvium and colluvium derived from basic igneous rock (Foote et al., 1972). The Helemano silty clay is neutral to moderately acidic well-drained dark reddish-brown soil (Foote et al., 1972). Mid-elevations are characterized by rocky soils (as in the Hahaione trail), while upper elevations on the ridgetops consists of rough mountainous land where a thin soil mantle (typically inceptisols) $2-35 \mathrm{~cm}$ lays over relatively soft and permeable saprolite (Foote et al., 1972). Typically the surface soils are poorly drained and weakly mineralized having a $2-6 \mathrm{~cm}$ thick litter and raw humic horizon, below which is a dark brown strongly acidic silty clay (Foote et al., 1972).

Tantalus (trails around Tantalus crater: Manoa Cliffs, Pauoa Flats, Ahiualama; Table 1) is the wettest location studied here, and is located on the leeward side of Koolau Range $\left(21^{\circ} 19^{\prime} 33^{\prime \prime} \mathrm{N}, 157^{\circ} 48^{\prime} 45^{\prime \prime} \mathrm{W}\right.$ to $21^{\circ} 20^{\prime} 31^{\prime \prime} \mathrm{N}, 157^{\circ} 48^{\prime} 04^{\prime \prime} \mathrm{W}$, elevation between 346 and $468 \mathrm{~m}$ ). This site supports wet rainforest with precipitation distributed almost equally between the months (Table 1). The dominant aliens are Bischofia javanica, Cestrum nocturnum, Citharexylum caudatum, Cinnamomum burmannii while A. koa, Freycinetia arborea, Hibiscus arnottianus and Metrosideros tremuloides are dominant native species. The soils are inceptisols of the Tantalus series - Tantalus silt loam and Tantalus silt clay. These are well-drained neutral to slightly acidic soils with very dark-brown A horizon on top of a dark reddishbrown sandy loam B horizon developed on volcanic ash and material weathered from cinders (Foote et al., 1972).

The four key soil types found across the sites rank according to the state of weathering as oxisols 
2174 J. PENUELAS et al.

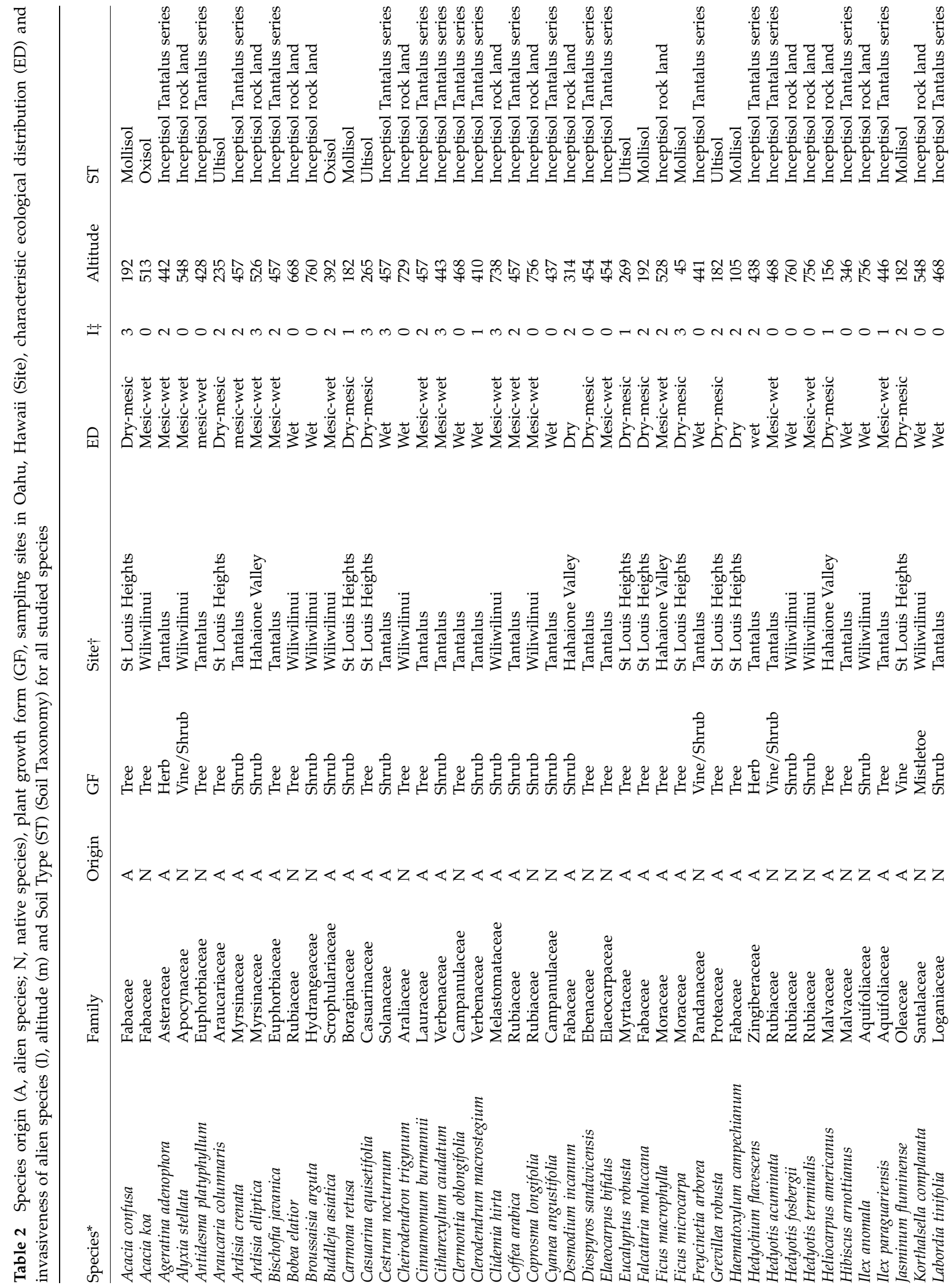




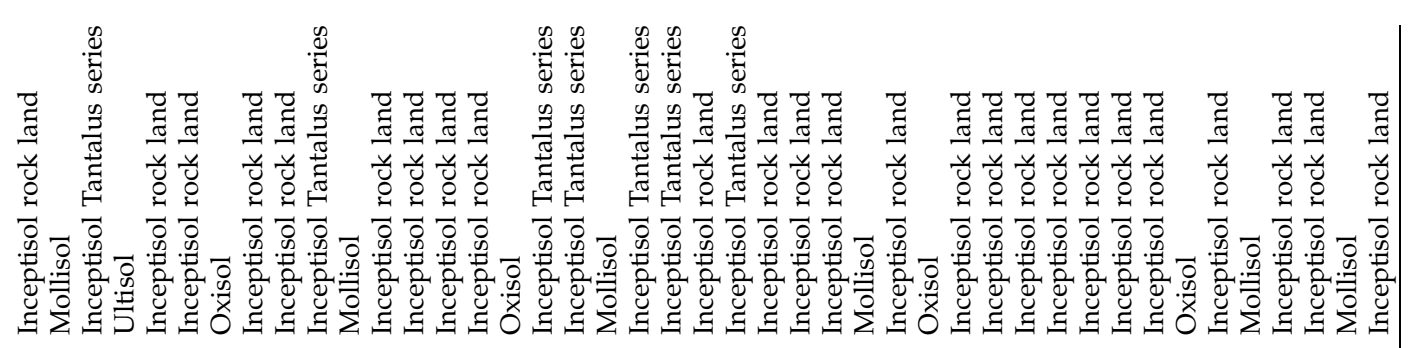

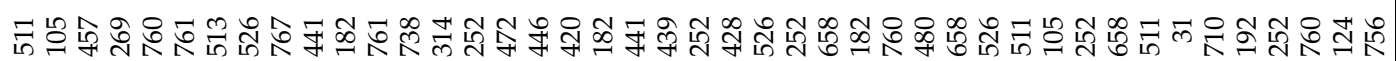

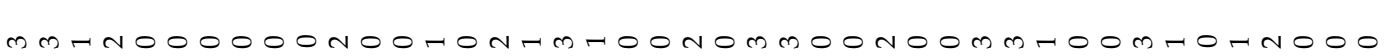

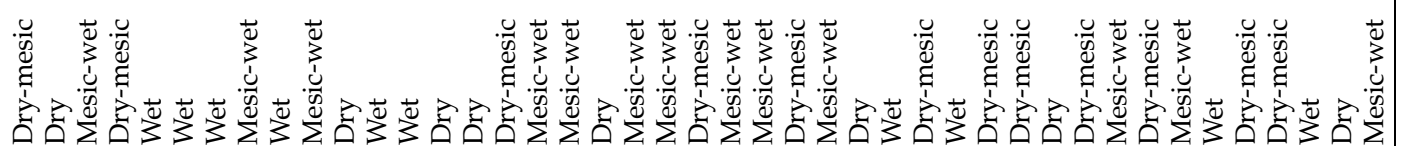

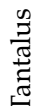

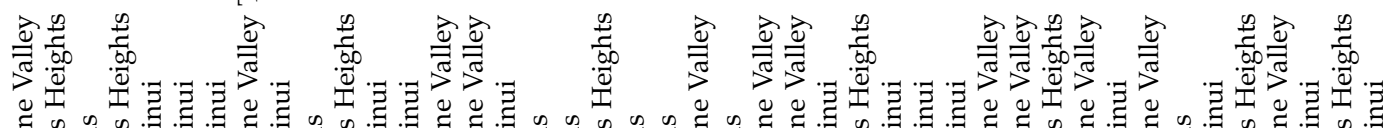

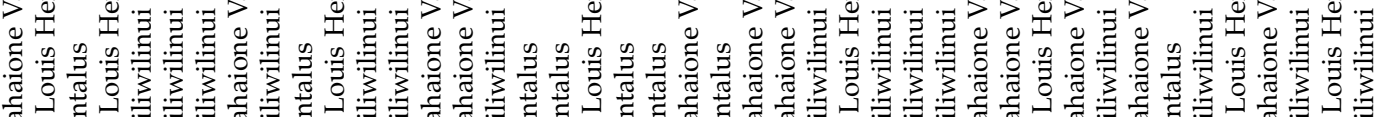

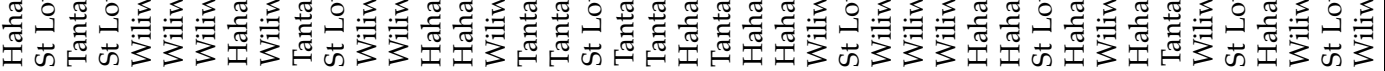

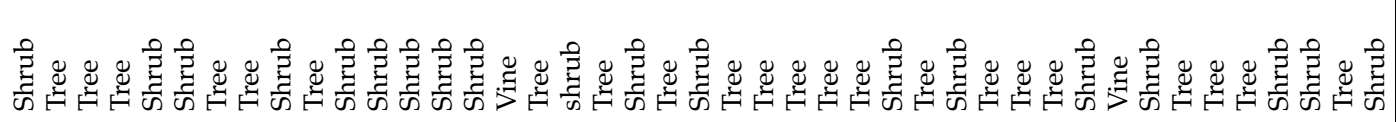
$\varangle \varangle \ll \varangle Z Z Z Z Z \varangle Z Z \varangle Z \varangle \varangle \varangle \varangle Z Z \varangle Z \varangle \varangle Z Z \varangle Z Z \varangle \varangle \varangle Z Z \varangle \varangle Z \varangle \varangle Z Z Z$

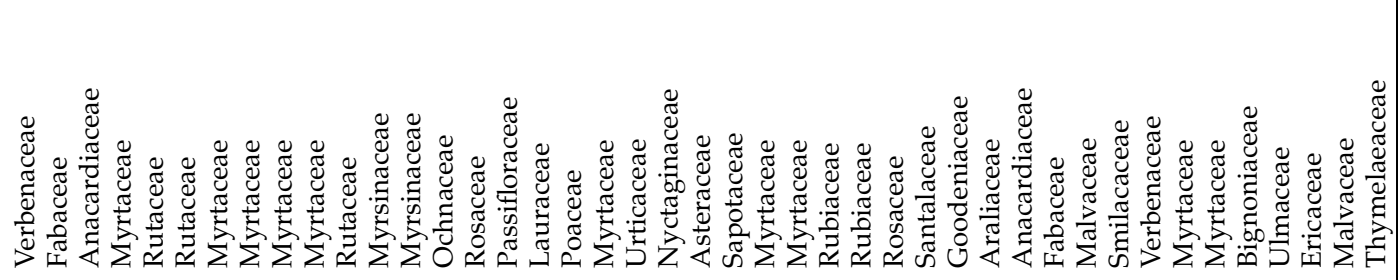

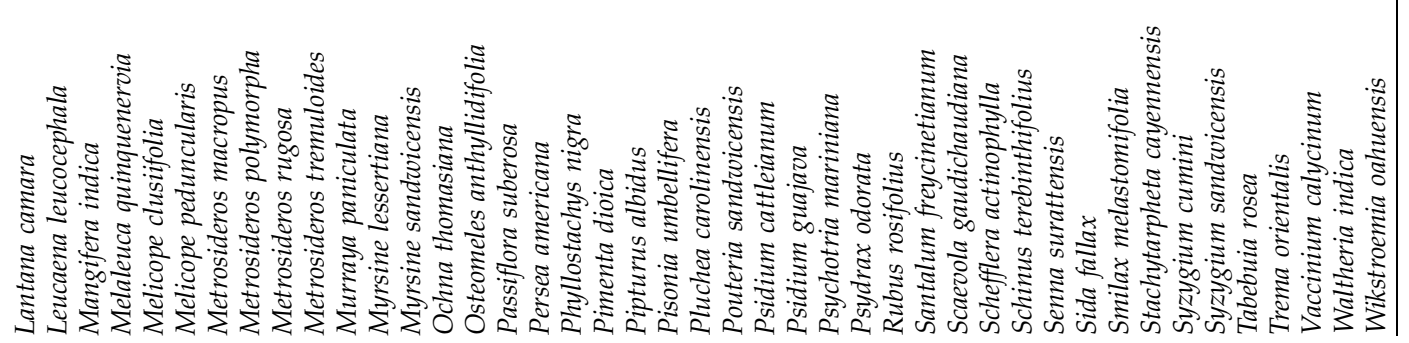

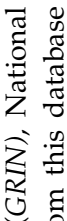
1 远 竞. : 官. $\stackrel{8}{\Xi}$ 产: : 空空

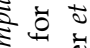
ษั घं है 药

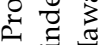
巳ु द्ञ ठ․

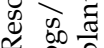
言 ह 듕

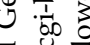
శี

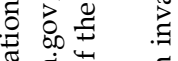
乙远岸 ) 즈 iे 运

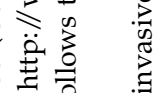

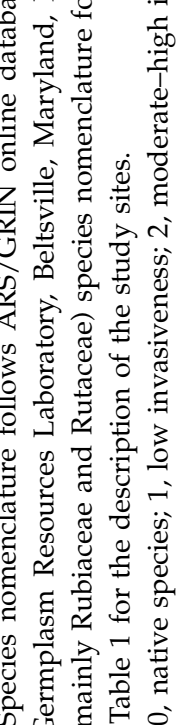


$>$ ultisols $>$ mollisols $>$ inceptisols (Uehara \& Ikawa, 2000; Deenik \& McClellan, 2007). Mollisols exhibit the highest fertility while more leached oxisols and ultisols with lower $\mathrm{pH}$ are among the soils with lowest fertility (Uehara \& Ikawa, 2000; Deenik \& McClellan, 2007) Inceptisols, the youngest soils, typically show weak profile development, and exhibit tremendous variability in fertility depending on genesis (Deenik \& McClellan, 2007). The Tantalus series of inceptisols are of moderate to high fertility, while the inceptisols in rocky soils and mountainous land are of low fertility. Thus, in our study, the broad soil classes rank according to fertility as mollisols $>$ inceptisols (Tantalus) $>$ oxisols $\cong$ ultisols $>$ inceptisols (mountainous soils).

\section{Plant sampling and site climate}

Owing to rough topography, gas-exchange measurements were conducted in the lab using cut twigs as is common in plant gas-exchange studies (Larcher, 1963; Ludlow, 1991; Kull \& Niinemets, 1998). Plant sampling for the gas-exchange follows the protocol of Niinemets et al. (2009). Twigs for the gas-exchange measurements were sampled in morning hours between 08:00 and 12:00 hours. The twigs were cut under water and retained in water in plastic bags with wet filter paper to stop transpiration during transportation to the lab. In the lab, the twigs were recut under water and stabilized at room temperature of $23-25^{\circ} \mathrm{C}$ in dim light. The measurements were conducted the next day. As the previous studies have demonstrated, this stabilization period is needed to achieve high stomatal openness and get maximum and stable values of net foliage assimilation rate (Niinemets et al., 2009). Control experiments demonstrated that stomatal conductance and photosynthesis immediately after shoot cutting were low, but recovered to maximum values after overnight stabilization. For each species, three individual plants were sampled. Species coordinates and sampling altitude were noted in each site using GPS, and this information was used to link species locations to specific soil types and to derive location-specific climatic data. Long-term average monthly and annual precipitation, precipitation of the 3 driest months and annual precipitation, and average, maximum and minimum temperatures were estimated from high-resolution climatic grids using the database developed and continuously updated by Giambelluca and associates (Giambelluca et al., 1986; Cao et al., 2007). ARCGIS 9.1 was used to extrapolate between the isohyets $(10 \mathrm{~m}$ square cells in the grid with appropriate elevation model), as applied previously in Hawaiian ecosystems (Porder et al., 2005; Dunbar-Co et al., 2009).

\section{Study species}

A total of 88 dominating species (i.e. species that are prevalent and cover a significant area in the sampled sites) were sampled in the four sites (three replicates per species), encompassing 41 native and 47 alien species (Table 2).

All native species sampled were evergreen, but some of the alien species, mostly legumes, collected in dry sites were drought-deciduous (Desmodium incanum, Falcataria moluccana, Senna surattensis, Tabebuia rosea) or semideciduous (H. campechianum, L. leucocephala). Out of the 88 studied species, 43 were trees, 36 shrubs, three woody vines to shrubs, three woody vines, two herbs to subshrubs and one mistletoe. The distribution of plant species among key plant functional types, shrubs and trees, was similar among alien and native species (18 shrubs for both aliens and native and 25 alien tree and 18 native tree species, Table 2 ). The species were classified according to site preference as dry, dry-mesic, mesic, dry-wet, mesic-wet and wet forest species. The invasiveness of species was scored using a four-level scale as 0 , native species; 1 , low invasiveness; 2 , moderate-high; and 3, very high (Table 2). These simplified scores were based on Australia/New Zealand weed risk assessment (WRA) system (Pheloung et al., 1999) modified to Hawaii and other Pacific Islands (Daehler et al., 2004). For Hawaiian Island these scores are reported in Pacific Island Ecosystems at Risk (PIER) project online database, maintained by US Forest Service's Institute of Pacific Islands Forestry (http:// www.hear.org/pier/), and on recent updates on species invasive potential in Oahu (Daehler \& Baker, 2006). The WRA is based on up to 49 questions about species biology. For nine species that have not been scored in these assessments, WRA scores were derived based on the risk questionnaire (http://www.hear.org/pier/). As the risk assessment provides information of possible species invasiveness, but not on whether the species actually becomes invasive in the specific new habitat, finally a simplified three-level scale (1-3) was used to group aliens with varying invasive potential and known invasiveness throughout Oahu. (Daehler et al., 2004; Daehler \& Baker, 2006).

\section{Leaf photosynthetic, structural and elemental analyses}

In the laboratory, foliar photosynthetic capacity was measured at a quantum flux density of $1000 \mu \mathrm{mol} \mathrm{m}^{-2} \mathrm{~s}^{-1}$ and leaf temperature of $25^{\circ} \mathrm{C}$ under ambient $\mathrm{CO}_{2}$ concentration of $385 \mu \mathrm{mol} \mathrm{mol}^{-1}$, using the twigs that had been recut under water and stabilized at room temperature of $23-25^{\circ} \mathrm{C}$. An ADC pro (LCpro + Portable Photosynthesis System; ADC BioScientific Ltd., Hoddesdon, 
Herts, EN11 0DB) gas exchange system was used. After the measurements the total leaf area and the leaf area enclosed in the cuvette were measured. In the laboratory, the area of 3-10 additional leaves per each sampled plant were measured with a LICOR LI-3100 area meter (LI-COR, Lincoln, NE, USA). For later analysis of trace element concentration only in foliar tissues, leaves were thoroughly washed with distilled water to remove the elements deposited on leaf surfaces. After washing, the samples were dried in an oven at $70{ }^{\circ} \mathrm{C}$ to a constant mass. Thereafter, dry mass of leaves was determined and leaf dry mass per area (LMA, $\mathrm{g} \mathrm{m}^{-2}$ ) was calculated. Mass-based photosynthetic capacity $\left(A_{\text {mass }}\right)$ was calculated as the area-based capacity divided by LMA. Dried plant material was further ground by a CYCLOTEC 1093 sample homogenizer (Foss Tecator, Höganäs, Sweden). In all cases, we washed the grinding system with bidistilled water between each other sample grinding to avoid sample contamination. For $\mathrm{C}$ and $\mathrm{N}$ analyses, $1-2 \mathrm{mg}$ of pulverized dried sample mixed with $2 \mathrm{mg}$ of $\mathrm{V}_{2} \mathrm{O}_{5}$ as oxidant was used. $\mathrm{C}$ and $\mathrm{N}$ concentrations were determined by combustion coupled to gas chromatography using a Thermo Electron Gas Chromatograph model NA 2100 (C.E. instruments-Thermo Electron, Milan, Italy). For analyses of other elements, samples were first solubilized with an acid mixture of $\mathrm{HNO}_{3}(60 \%)$ (143255, purissimum, PANREAC, Barcelona) and $\mathrm{HClO}_{4}(60 \%)$ (141054, purissimum, PANREAC, Barcelona) $(2: 1)$ in a microwave oven (SAMSUNG, TDS, Seoul, South Korea) using Oak Ridge $50 \mathrm{~mL}$ Teflon centrifuge tubes (Nalge Nunc International, Rochester, NY, USA). Two milliliters of the acidic solution were used per $100 \mathrm{mg}$ of dry biomass of each sample. The digested solutions were thereafter brought to $10 \mathrm{~mL}$ of final volume (with $3 \%$ of $\mathrm{HClO}_{4}$ solution). Blank solutions ( $2 \mathrm{~mL}$ of acid mixture without any sample biomass) were regularly analyzed. To assess the accuracy of digestion and the analytical biomass procedures, standard certified biomass (DC73351, leaf poplar, China National Analysis Center for Iron \& Steel, Beijing, China) was used. After digestion, the concentrations of $\mathrm{As}, \mathrm{Cd}, \mathrm{Cr}, \mathrm{Cu}, \mathrm{Fe}, \mathrm{Mn}, \mathrm{Ni}, \mathrm{Pb}$, $\mathrm{Sr}, \mathrm{V}, \mathrm{Zn}, \mathrm{Ca}, \mathrm{K}, \mathrm{Na}, \mathrm{Mg}, \mathrm{S}, \mathrm{P}$ and Mo were analyzed using ICP-MS (Mass Spectroscopy with Inductively Coupled Plasma). With this method, low detection thresholds can be obtained for elements such as metalloids (e.g. As) with high ionization energies. For As analyses, As (V) was reduced to As (III) by a mixture of $\mathrm{HCl}(30 \% \mathrm{v} / \mathrm{w}), \mathrm{KI}(1 \% \mathrm{w} / \mathrm{v})$ and ascorbic acid $(0.2 \% \mathrm{w} / \mathrm{v})$ was added to a digestion solution aliquot of each sample. This solution was then pumped into a gas-liquid separator where it reacted with $\mathrm{NaBH}_{4}$ $(1.3 \% \mathrm{w} / \mathrm{v}$ solution in $0.1 \mathrm{M} \mathrm{NaOH})$ to form arsenic hydrides and analyzed with ICP-MS. Plant-specific measurements of $A_{\text {mass }}$ LMA and foliage element con- centrations were averaged to get species-specific averages for all characteristics.

\section{Phylogenetic and statistical analyses}

The program PHYLOMATIC (Webb \& Donoghue, 2005) was used to build a phylogenetic tree of the species studied (Fig. 1). Briefly, this program assembles a phylogeny for the species of interest employing a backbone plant megatree based on a variety of sources involving primarily DNA studies. Our phylogenetic hypothesis was based on the conservative megatree, where unresolved nodes were included as soft politomies. We employed programs in the PDAP package (Garland et al., 1993) to transform the phylogenetic tree into a matrix of phylogenetic distances, and assessed if the studied traits showed significant phylogenetic signal i.e. the tendency of closely related species to resemble each other due to shared ancestry - employing the randomization procedure in the PHYSIG module developed by Blomberg et al. (2003). This test consists in comparing the variance in phylogenetic independent contrasts observed in the real dataset against a null distribution obtained after the phenotypic data were randomized across the tips of the phylogeny (i.e. breaking any pattern of phylogenetic resemblance between relatives). Phylogenetic signal was considered significant if the variance in contrasts of the real dataset was lower than the variance in $95 \%$ of the permuted datasets. To perform comparisons across traits, we employed the $k$ statistic, that estimates how much phylogenetic signal is present in the phenotypic data compared against the expectation from a random walk model of phenotypic evolution (Blomberg et al., 2003). If $k=1$, then the phenotypic trait has exactly the amount of signal expected for the phylogenetic tree employed and a model of evolution of random walk (Brownian motion); $k>1$ indicates a stronger phylogenetic resemblance than expected and $k<1$ the opposite pattern. These analyses were performed to determine if phylogenetic correction was necessary in subsequent regression analyses. We employed generalized linear models (GLM) to analyze how chemical, structural and physiological leaf traits varied as a function of collecting site (four different sample sites), species origin (native or alien) and soil type (five different soil types), that were included as independent categorical variables. Preliminary analyses showed that altitude was significantly correlated with all climate variables studied here (analyses not shown), hence we included altitude as surrogate covariate for climate conditions in these models when there was a significant trend for foliar traits to change with altitude (Table 3). We employed ordinary least square regressions (OLS) when the dependent 


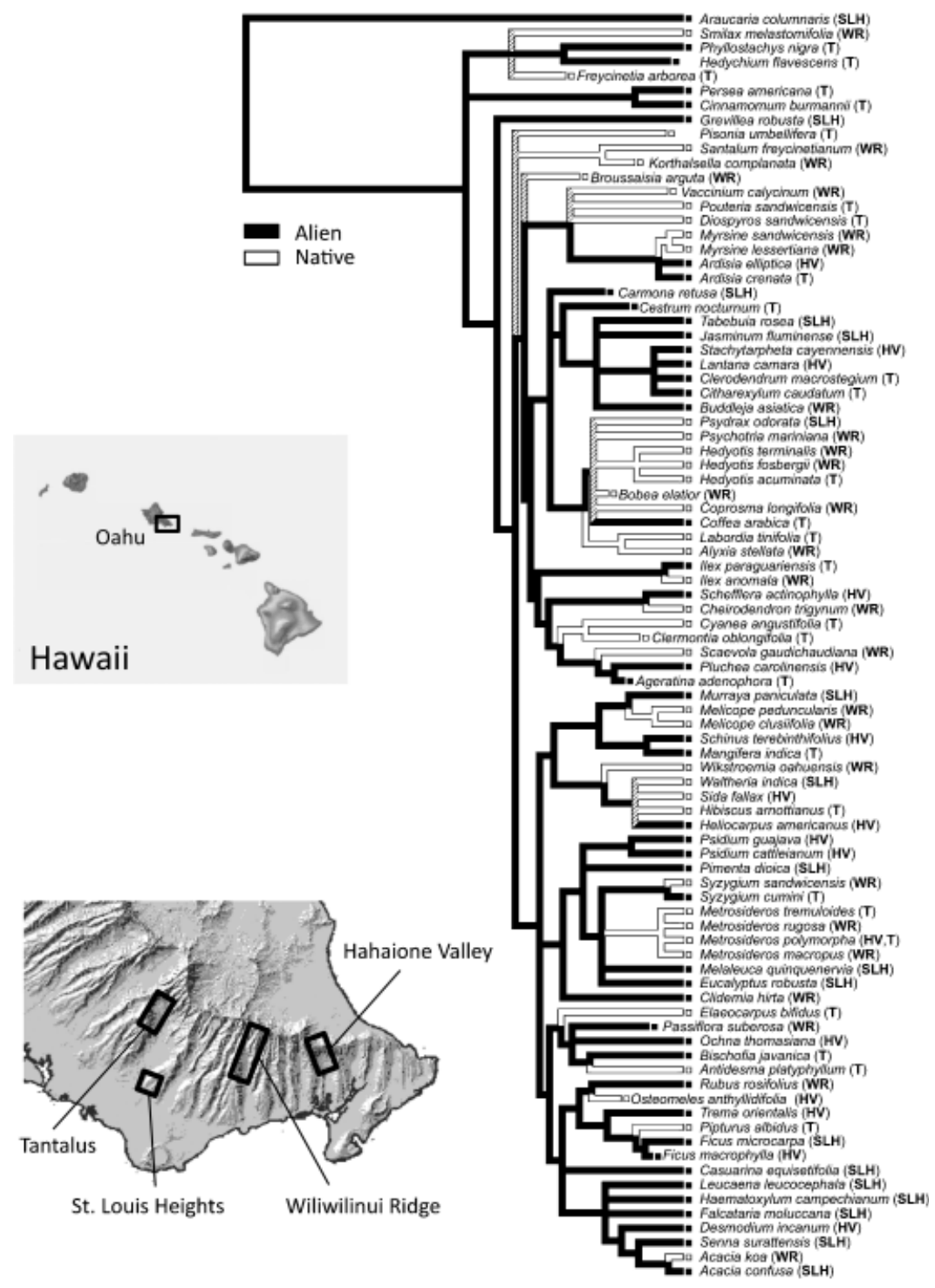

Fig. 1 Phylogenetic tree of the woody plant species studied. The phylogenetic tree was constructed with the program PHYLOMATIC (Webb \& Donoghue, 2005). The branch colors depict the ancestral character state obtained with parsimony (the transition from native to alien species is constrained since it involves three independent colonization events). Analyses were performed with Mesquite (Maddison \& Maddison, 2009). Field collection sites (HV, Hahaione Valley; T, Tantalus; SLH, St Louis Heights; WR, Wiliwilinui Ridge) for each species are depicted after the species name.

variable did not show significant phylogenetic signal, and phylogenetic generalized least square regressions (PGLS) otherwise. PGLS controls for phylogenetic relatedness by adjusting the expected variance/covariance of regression residuals employing the matrix of phylogenetic distances (this approach is mathematically equivalent to analyzing the data employing phylogenetically independent contrasts). These analyses were performed in MATLAB 7.6.0 employing the REGRESSIONV2 module (Lavin et al., 2008). We employed the same rationale to analyze potential differences in foliar economics spectrum. All data were log-transformed for analysis. First, we conducted a GLM analysis with $A_{\text {mass }}$ as dependent variable and LMA and leaf nutrient concentrations as continuous independent variables and species origin (alien or native) as a categorical independent variable. Subsequently, separate GLM analyses were conducted with leaf morphological, chemical and physiological traits as dependent variables, surrogates of climate (mean annual precipitation and mean annual temperature) as continuous independent variables and species origin as a categorical independent variable. As described above, OLS or PGLS analyses were selected depending on the amount of phylogenetic 
Table 3 Association between species leaf traits and phylogeny (phylogenetic effects were estimated with the PHYSIG randomization procedure) and values of the studied chemical, structural and physiological variables in native species, in lowly invasive species and in highly invasive species

\begin{tabular}{|c|c|c|c|c|c|c|c|c|}
\hline \multirow[b]{2}{*}{ Foliar trait } & \multirow[b]{2}{*}{ Units } & \multicolumn{2}{|c|}{ Phylogeny } & \multirow[b]{2}{*}{ Model } & \multirow[b]{2}{*}{ Native } & \multicolumn{2}{|c|}{ Invasiveness } & \multirow[b]{2}{*}{$P$-value } \\
\hline & & K & $P$-value & & & Low & High & \\
\hline$A_{\text {mass }}$ & $\mu \mathrm{molg}{ }^{-1} \mathrm{~s}^{-1}$ & 0.446 & $<0.01$ & PGLS & $\begin{array}{l}\mathbf{0 . 0 8}^{\mathbf{b}} \\
(0.01)\end{array}$ & $\begin{array}{c}\mathbf{0 . 1 2}^{\mathbf{a}} \\
(0.03)\end{array}$ & $\begin{array}{l}\mathbf{0 . 1 6} \\
(0.02)\end{array}$ & $<0.01$ \\
\hline LMA & $\mathrm{g} \mathrm{m}^{-2}$ & 2.120 & $<0.001$ & PGLS & $\begin{array}{l}\mathbf{1 2 6}^{\mathbf{a}} \\
(11)\end{array}$ & $\begin{array}{l}\mathbf{9 7}^{\mathbf{b}} \\
(21.0)\end{array}$ & $\begin{array}{l}105^{\mathbf{b}} \\
(12)\end{array}$ & $<0.01$ \\
\hline $\mathrm{N}$ & $\%$ & 0.420 & $<0.001$ & PGLS & $\begin{array}{l}1.8^{\mathbf{a}} \\
(0.1)\end{array}$ & $\begin{array}{l}2.2^{a b} \\
(0.2)\end{array}$ & $\begin{array}{l}2.4^{\mathrm{a}} \\
(0.1)\end{array}$ & $<0.0001$ \\
\hline K & $\mathrm{mg} \mathrm{g}^{-1}$ & 0.270 & $<0.05$ & PGLS & $\begin{array}{l}7.7^{\mathbf{b}} \\
(0.7)\end{array}$ & $\begin{array}{r}9.6^{a} \\
(1.3)\end{array}$ & $\begin{array}{l}\mathbf{1 0 . 6}^{\mathbf{a}} \\
(0.8)\end{array}$ & $<0.001$ \\
\hline $\mathrm{C} / \mathrm{N}$ & & 0.442 & 0.071 & PGLS & $\begin{array}{l}31^{\mathbf{a}} \\
(2)\end{array}$ & $\begin{array}{l}\mathbf{2 6 ^ { b }} \\
(2)\end{array}$ & $\begin{array}{l}\mathbf{2 3 ^ { \mathbf { b } }} \\
(1)\end{array}$ & $<0.001$ \\
\hline $\mathrm{Fe}$ & $\mathrm{mg} \mathrm{kg}^{-1}$ & 0.231 & 0.37 & OLS & $\begin{array}{l}\mathbf{6 2}^{\mathbf{b}} \\
(7)\end{array}$ & $\begin{array}{l}\mathbf{1 0 6}^{\mathbf{a}} \\
(13)\end{array}$ & $\begin{array}{l}103^{a} \\
(8)\end{array}$ & $<0.001$ \\
\hline $\mathrm{Cu}$ & $\mathrm{mg} \mathrm{kg}^{-1}$ & 0.326 & 0.075 & PGLS & $\begin{array}{l}\mathbf{6 .} \mathbf{7}^{\mathbf{b}} \\
(0.9)\end{array}$ & $\begin{array}{l}10.8^{\mathbf{a}} \\
(1.8)\end{array}$ & $\begin{array}{l}9.1^{\mathbf{a}} \\
(1.0)\end{array}$ & $<0.001$ \\
\hline $\mathrm{Na}$ & $\mathrm{mg} \mathrm{g}^{-1}$ & 0.251 & 0.19 & OLS & $\begin{array}{l}4.8^{\mathrm{a}} \\
(0.5)\end{array}$ & $\begin{array}{l}1.7^{\mathbf{b}} \\
(0.8)\end{array}$ & $\begin{array}{l}2.8^{\mathbf{b}} \\
(0.5)\end{array}$ & $<0.01$ \\
\hline $\mathrm{Ni}$ & $\mu \mathrm{g} \mathrm{kg}^{-1}$ & 0.359 & $<0.01$ & PGLS & $\begin{array}{l}\mathbf{2 9 4 8} \mathbf{b}^{\mathbf{b}} \\
(948)\end{array}$ & $\begin{array}{r}8493^{\mathbf{a}} \\
(1751)\end{array}$ & $\begin{array}{l}\mathbf{6 2 0 4 ^ { a }} \\
(1024)\end{array}$ & $<0.05$ \\
\hline $\mathrm{Zn}$ & $\mathrm{mg} \mathrm{kg}^{-1}$ & 0.354 & 0.057 & PGLS & $\begin{array}{l}\mathbf{2 2}^{\mathbf{b}} \\
(1)\end{array}$ & $\begin{array}{l}\mathbf{2 0}^{\mathbf{b}} \\
(7)\end{array}$ & $\begin{array}{l}32^{\mathrm{a}} \\
(4)\end{array}$ & $<0.05$ \\
\hline As & $\mu \mathrm{g} \mathrm{kg}^{-1}$ & 0.328 & 0.17 & OLS & $\begin{array}{l}85 \\
(12)\end{array}$ & $\begin{array}{l}65 \\
(22)\end{array}$ & $\begin{array}{l}86 \\
(13)\end{array}$ & 0.71 \\
\hline C & $\%$ & 0.287 & $<0.01$ & PGLS & $\begin{array}{l}48 \\
(0.5)\end{array}$ & $\begin{array}{l}49 \\
(0.8)\end{array}$ & $\begin{array}{l}48 \\
(0.5)\end{array}$ & 0.22 \\
\hline $\mathrm{Ca}$ & $\mathrm{mg} \mathrm{g}^{-1}$ & 0.290 & 0.17 & OLS & $\begin{array}{l}12.2 \\
(1.0)\end{array}$ & $\begin{array}{l}9.51 \\
(1.93)\end{array}$ & $\begin{array}{l}12.1 \\
(1.1)\end{array}$ & 0.62 \\
\hline $\mathrm{Cd}$ & $\mu \mathrm{g} \mathrm{kg}^{-1}$ & 0.308 & 0.072 & PGLS & $\begin{array}{l}117 \\
(24)\end{array}$ & $\begin{array}{l}73 \\
(45)\end{array}$ & $\begin{array}{l}86 \\
(26)\end{array}$ & 0.21 \\
\hline $\mathrm{Cr}$ & $\mu \mathrm{g} \mathrm{kg}^{-1}$ & 0.269 & 0.41 & OLS & $\begin{array}{l}535 \\
(242)\end{array}$ & $\begin{array}{l}949 \\
(450)\end{array}$ & $\begin{array}{l}1299 \\
(263)\end{array}$ & 0.18 \\
\hline $\mathrm{C} / \mathrm{P}$ & & 0.256 & 0.13 & OLS & $\begin{array}{l}620 \\
(47)\end{array}$ & $\begin{array}{l}583 \\
(88)\end{array}$ & $\begin{array}{l}507 \\
(52)\end{array}$ & 0.41 \\
\hline $\mathrm{Mg}$ & $\mathrm{mgg}^{-1}$ & 0.300 & $<0.05$ & PGLS & $\begin{array}{l}4.8 \\
(0.5)\end{array}$ & $\begin{array}{l}4.7 \\
(0.8)\end{array}$ & $\begin{array}{l}5.7 \\
(0.5)\end{array}$ & 0.25 \\
\hline $\mathrm{Mn}$ & $\mathrm{mg} \mathrm{kg}^{-1}$ & 0.538 & $<0.05$ & PGLS & $\begin{array}{l}296 \\
(55)\end{array}$ & $\begin{array}{l}327 \\
(102)\end{array}$ & $\begin{array}{l}294 \\
(60)\end{array}$ & 0.11 \\
\hline Mo & $\mu \mathrm{g} \mathrm{kg}^{-1}$ & 0.203 & 0.58 & OLS & $\begin{array}{l}271 \\
(53)\end{array}$ & $\begin{array}{l}249 \\
(99)\end{array}$ & $\begin{array}{l}244 \\
(58)\end{array}$ & 0.97 \\
\hline $\mathrm{N} / \mathrm{P}$ & & 0.270 & 0.12 & OLS & $\begin{array}{l}20 \\
(1)\end{array}$ & $\begin{array}{l}23 \\
(3)\end{array}$ & $\begin{array}{l}23 \\
(2)\end{array}$ & 0.49 \\
\hline $\mathrm{P}$ & $\mathrm{mg} \mathrm{g}^{-1}$ & 0.307 & 0.064 & PGLS & $\begin{array}{l}1.04 \\
(0.10)\end{array}$ & $\begin{array}{l}1.00 \\
(0.19)\end{array}$ & $\begin{array}{l}1.22 \\
(0.11)\end{array}$ & 0.37 \\
\hline $\mathrm{Pb}$ & $\mu \mathrm{g} \mathrm{kg}^{-1}$ & 0.228 & 0.62 & OLS & $\begin{array}{l}1350 \\
(140)\end{array}$ & $\begin{array}{l}822 \\
(259)\end{array}$ & $\begin{array}{l}422 \\
(151)\end{array}$ & 0.44 \\
\hline$S$ & $\mathrm{mgg}^{-1}$ & 0.299 & 0.28 & OLS & $\begin{array}{l}2.35 \\
(0.26)\end{array}$ & $\begin{array}{l}2.02 \\
(0.46)\end{array}$ & $\begin{array}{l}2.51 \\
(0.28)\end{array}$ & 0.83 \\
\hline $\mathrm{Sr}$ & $\mathrm{mg} \mathrm{kg}^{-1}$ & 0.308 & 0.89 & OLS & $\begin{array}{l}108 \\
(14)\end{array}$ & $\begin{array}{l}62 \\
(25)\end{array}$ & $\begin{array}{l}80 \\
(15)\end{array}$ & 0.35 \\
\hline V & $\mu \mathrm{g} \mathrm{kg}^{-1}$ & 0.308 & 0.89 & OLS & $\begin{array}{l}129 \\
(17)\end{array}$ & $\begin{array}{l}150 \\
(30)\end{array}$ & $\begin{array}{l}158 \\
(18)\end{array}$ & 0.52 \\
\hline
\end{tabular}

Significant results $(P<0.05)$ are highlighted in bold. Different letters indicate significant differences.

$P$-values indicate the results of general linear models controlling for altitude (when significant), type of soils and site. Numbers within parentheses are SEM. OLS, Ordinary least squares regression; PGLS, phylogenetic generalized least squares regression. 
signal observed in the preliminary randomization analysis.

Finally, we employed logistic regression analyses to determine how the presence/absence of alien and native species varied as a function of altitude and climate, and principal component analyses (PCA) to determine how the chemical elements could discriminate between alien and native species in the PC space. We employed a one-way ANOVA to determine how PC scores obtained for the first and second components differed between native and alien species. These analyses were performed with STATVIEW 5.0.1 (SAS Institute Inc., Cary, NC, USA) and STATISTICA 6.0 (StatSoft Inc., Tule, OK, USA).

\section{Results}

Phylogenetic signal was statistically significant $(P<0.05)$ for eight traits and bordered significance $(P<0.075)$ in other five out of the 24 studied foliar traits (Table 3). The foliar traits with the highest phylogenetic signal estimated with the $k$ statistic were LMA, leaf $\mathrm{N}$ concentration and $A_{\text {mass }}$. Phylogenetic signal was also detected in $\mathrm{C}, \mathrm{Cd}, \mathrm{Cu}, \mathrm{K}, \mathrm{Mg}, \mathrm{Mn}, \mathrm{Ni}, \mathrm{P}$ and $\mathrm{Zn}$ leaf concentrations (Table 3), although in $\mathrm{Cd}, \mathrm{Cu}$ and $\mathrm{Zn}$ the phylogenetic signal only bordered the significance (Table 3). Moreover, the species origin (native or alien) (Fig. 1) and the alien species invasiveness (low or high) also presented significant phylogenetic signal $(P=0.03$ and 0.04 , respectively).

Invasive species had on average $100 \%$ higher $A_{\text {mass }}$ and $17 \%$ lower LMA than native species. Invasive species had significantly higher foliar $\mathrm{N}(33 \%), \mathrm{K}$ (38\%), Fe (66\%), Ni (110\%), Cu (36\%) and Zn (45\%) concentrations, and lower $\mathrm{Na}(42 \%)$ concentrations and $\mathrm{C} / \mathrm{N}$ ratio (26\%) than the native species (Tables 3 and 4 ). The differences relative to the native species were more pronounced in the highly invasive species than in the lowly invasive species, e.g. for $A_{\text {mass }}, \mathrm{N}, \mathrm{K}$ or $\mathrm{C} / \mathrm{N}$ ratio (Table 3). However, the differences between these low and high invasiveness groups were not significant (Table 3). Higher $\mathrm{N}$ content in aliens was not due to the larger number of $\mathrm{N}$-fixers among them, as aliens also had greater $\mathrm{N}$ concentrations than native species when considering only the non $\mathrm{N}$-fixer species $(2.23 \pm 0.11$ vs. $1.75 \pm 0.11, P<0.001)$.

$A_{\text {mass }}$ related negatively to LMA and positively to foliar $\mathrm{N}$ concentrations (Fig. 2) and also to the other nutrient concentrations such as $\mathrm{P}$ or $\mathrm{K}$ (data not shown) both in alien and invasive species. The highest $A_{\text {mass }}$ values were observed at lower LMA and higher N (Fig. 2), $\mathrm{P}$ and $\mathrm{K}$ concentrations. The position along this leaf economics spectrum differed between native and invasive species with significant shifts in group means along a common slope, the alien having higher $A_{\text {mass }}$ and $\mathrm{N}$ concentrations and lower LMA (Fig. 2). They also had more interspecific variability than native ones (Fig. 2).

Invasive species and native species were also significantly separated $(P<0.001$ for both $P C 1$ and $P C 2)$ in the PCA space defined by the two first PCA factors resulting from the leaf concentrations of the elements that exhibited significant differences between the invasive and the native species, i.e. $\mathrm{N}, \mathrm{K}, \mathrm{Na}, \mathrm{Fe}, \mathrm{Zn}, \mathrm{Cu}$ and $\mathrm{Ni}$ (Fig. 3). The two main factors of PCA explained $35.6 \%$ and $15.4 \%$ of the total variance of elemental concentrations, respectively (Fig. 3). The invasive species occupied the space with higher $\mathrm{N}, \mathrm{K}, \mathrm{Fe}, \mathrm{Zn}$ and $\mathrm{Cu}$ concentrations (PC1) and higher $\mathrm{Ni}$ concentrations and lower Na concentrations (PC2).

\section{Discussion}

Invasive species had higher $A_{\text {mass }}$ and lower LMA, and therefore lower leaf construction cost in terms of biomass investment in leaves. They had thus higher photosynthetic returns from their foliar biomass investment. Similar results have been reported by Leishman et al. (2007) for temperate Australian ecosystems, and more recently, Feng et al. (2009) have also reported that alien populations of Ageratina adenophora throughout the subtropics have evolved increasing $\mathrm{N}$ allocation to photosynthesis (growth) and reduced allocation to cell walls. Our results confirm that this strategy is a general trait in invasive species in Oahu Island. Such quicker returns may contribute to increase growth and photosynthetic productivity of invasive species at a lower leaf cost, thereby conferring a competitive advantage over native species, especially when being introduced to novel environments where resources are not strongly limited. The differences relative to the native species tended to be only slightly more pronounced in the highly invasive species than in the lowly invasive species (Table 3).

The alien-invasive species shifted further along the leaf economics spectrum toward faster growth strategies than co-occurring native species, but still along a common slope in the relationships between $A_{\text {mass }}$ and LMA, N, P and K. Hence, alien-invasive plants did not have fundamentally different carbon capture strategies from natives. Our results thus do not show higher efficiency of invasive plants at using limiting nutrient resources as recently reported (Funk \& Vitousek, 2007). They just show alien-invasive species had higher concentrations of nutrients.

Our results, besides providing support to those previous studies that showed that invasive plants accumulate more $\mathrm{N}$ and/or $\mathrm{P}$ than the co-occurring natives (Ashton et al., 2005; Dassonville et al., 2007), 


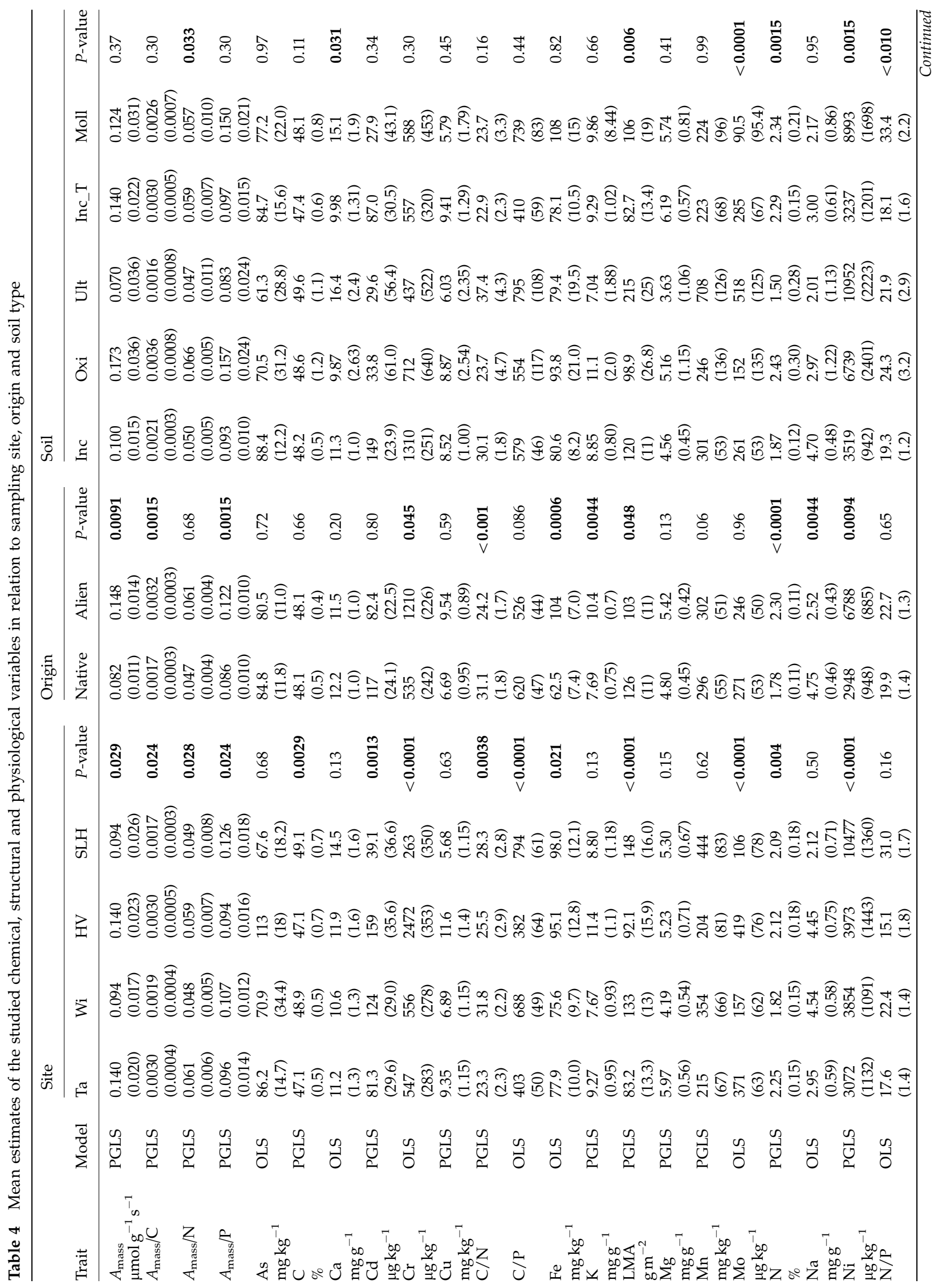


extended previous studies by analyzing a whole set of macro- and micronutrients and trace elements in addition to $\mathrm{N}$ and $\mathrm{P}$. This extension has allowed finding out a clear separation between invasive and native species in the elemental concentrations PCA space, thus showing segregation in their biogeochemical niche (Peñuelas et al., 2008). This segregation suggests that these species may be using different resources and might also have greater capacities to capture and use nutrients. The different soil chemistry of the different sites did not explain these different biogeochemical niches of alien and native plants as indicated by the significant differences between native and alien species in $\mathrm{Cr}$, $\mathrm{Fe}, \mathrm{K}$ and $\mathrm{Na}$ foliar concentrations without any significant difference among sites, or the significant differences in foliar $\mathrm{P}$ concentrations among sites without a significant difference between alien and native species (Table 4).

Our results suggest that not only $\mathrm{N}$ and $\mathrm{K}$ can be involved in this ecological strategy of invasive plants. Other elements such as $\mathrm{Fe}$, which is linked to plant photosynthetic capacity, can also be captured rapidly by invasive plants, and the cycling of these elements could also be accelerated in invasive alien-dominated ecosystems. The concentrations of potentially toxic trace elements such as $\mathrm{Zn}, \mathrm{Cu}$ and $\mathrm{Ni}$ were also higher in invasive species than in native species. However, the leaf concentrations of these trace elements observed in the studied plants are mostly in the range of leaf concentrations observed in nonpolluted areas throughout the world and are considerably lower than potentially toxic concentrations causing leaf damage (Sardans \& Peñuelas, 2007).

An invasion by alien plant species seems to be favored when nutrient availability increases, as observed not only in tropical ecosystems such as the studied here but also in others such as temperate forests (Howard et al., 2004) and grasslands (Cassidy et al., 2004), or Mediterranean shrublands (Thomson \& Leishman, 2005; Sala et al., 2007). Recently, in a study of a database of 52480 vegetation plots in three European temperate regions (Catalonia with Mediterranean climate, Czech Republic with subcontinental climate and Great Britain with oceanic climate), Chytry et al. (2008) observed that whereas only few alien species were found in nutrient-poor plots, many alien species were found in frequently disturbed habitats with fluctuating nutrient availability. Moreover, the probability of aliens reaching frequently disturbed habitats is higher than that of reaching undisturbed habitats. Our results together with these previous studies show thus that human driven processes such as atmospheric pollution, fertilization or introduction of alien species, which itself results in an increasing nutrient availability (Hughes \& 

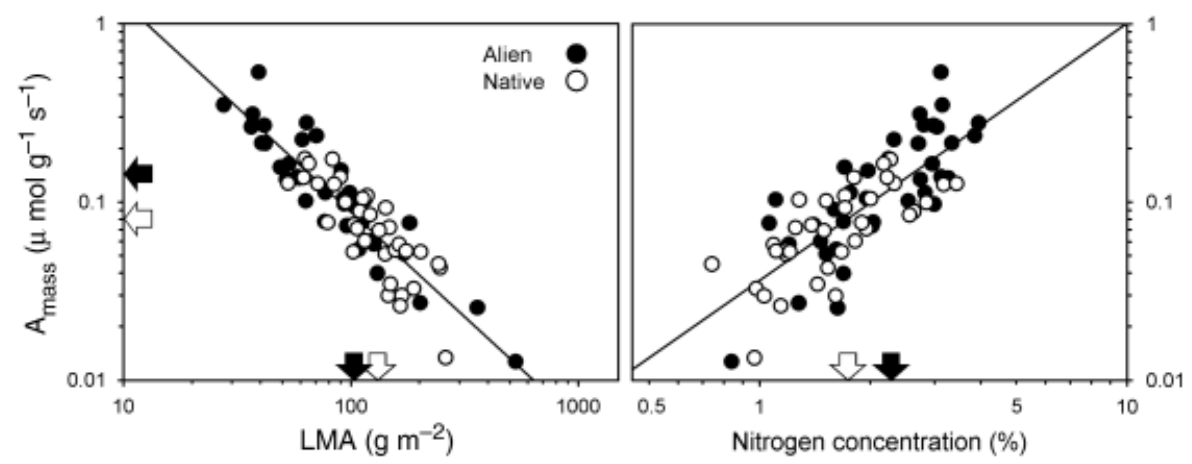

Fig. 2 Photosynthetic capacity per unit leaf dry mass $\left(A_{\text {mass }}\right)\left(\mu \mathrm{mol} \mathrm{g}^{-1} \mathrm{~s}^{-1}\right)$ as a function of leaf mass per area (LMA) $\left(\mathrm{g} \mathrm{m}^{-2}\right)$ and foliar $\mathrm{N}$ concentrations (\% dry weight) in native and invasive plant species. The variables are plotted in logarithmic scale. A multiple regression including LMA and $\mathrm{N}$ show that both variables are significantly associated with $A_{\text {mass. }}$. Alien species present significantly higher $A_{\text {mass }}$ and $\mathrm{N}$ and lower LMA (Table 3). Arrows indicate the arithmetic means obtained for each group. Similar relationships to those of $\mathrm{N}$ were found for the other nutrients such as $\mathrm{P}$ or $\mathrm{K}$.
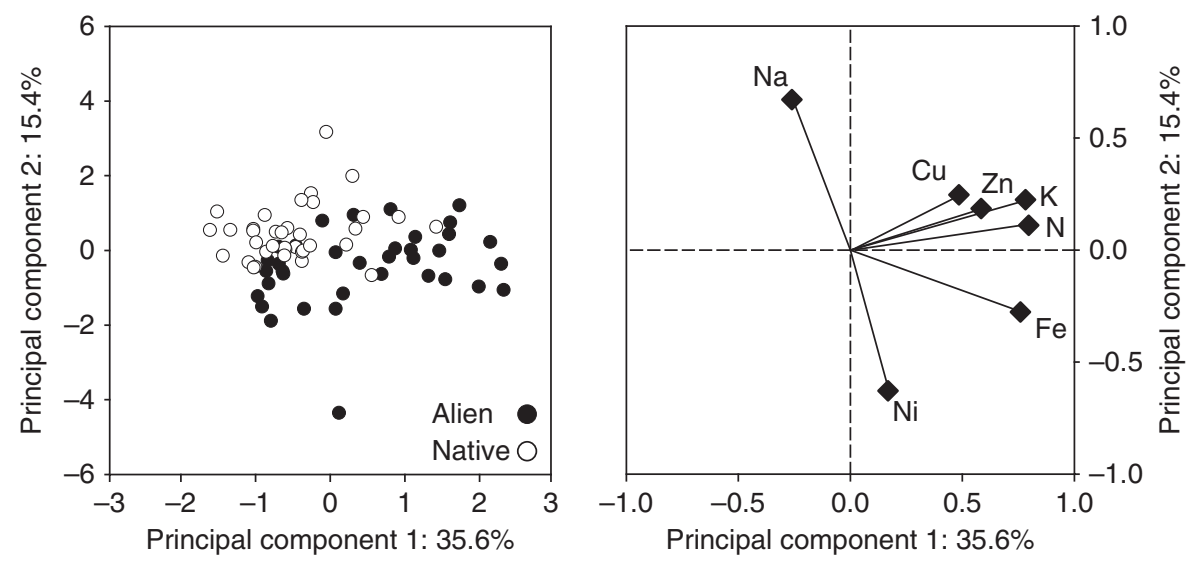

Fig. 3 Distribution of invasive and native species occupying a different 'biogeochemical niche' in the space determined by the two first principal components, PC1 and PC2, of the principal component analyses (PCA) conducted with foliar elemental concentrations of N, K, $\mathrm{Na}, \mathrm{Fe}, \mathrm{Zn}, \mathrm{Ni}$ and $\mathrm{Cu}$.

Denslow, 2005; Hughes \& Uowolo, 2006; Sala et al., 2007; Kurten et al., 2008), can favor the invasion success by increasing the presence of the current alien species or by the establishment of new alien species (Sala et al., 2007; Kurten et al., 2008). N and P fertilization have already been reported to increase the abundance of alien species in Hawaiian forests (Ostertag \& Verville, 2002).

The results presented here extend previous studies to a long list of species for which phylogenetic signal has now here been considered. Apart from allowing the removal of the effects of the phylogenetic history, such exercise has also shown a significant phylogenetic signal for the species origin (native or alien) and for the alien species invasiveness (low or high), indicating that species from some families have greater possibilities to establish as alien species. For example, Fabaceae species are known to be very frequent among the most successful invaders in Hawaii (Hughes \& Denslow, 2005; Hughes \& Uowolo, 2006).
The combination of the traits described here, rapid growth and occupation of a different biogeochemical niche, with other traits such as a lower pathogen and herbivore burden (Blumenthal et al., 2009) seem to set the alien-invasive plants apart from the native plants. These traits should hence be considered on environmental and biodiversity management.

We thus conclude (i) that the species set composition and most foliar traits of native and invasive species have a significant phylogenetic signal, (ii) that the alien success is related to faster returns from their investments in dry mass in leaves, (iii) that the higher concentrations of most nutrients and some trace elements place alien species in a different biogeochemical niche than native species, (iv) that all these differences remain highly significant after removing the effects of phylogenetic history, (v) that alien-invasive species did not show higher efficiency at using limiting nutrient resources and (vi) that aliens' invasive success may in 
consequence be favored by increasing habitats disturbance and eutrophication.

\section{Acknowledgements}

We thank the G. P. Wilder Chair allocated to ÜN at the Department of Botany, University of Hawaii at Manoa, Hawaii. We also thank the students, faculty and staff of that Department for making available laboratory space and equipment for this research. We thank Theodore Garland Jr for providing the statistical programs used for phylogenetic analyses. This research was supported by the University of Hawaii (G. P. Wilder research funds), and the grants from the Spanish Government (CGL2006-04025/BOS and Consolider-Ingenio Montes CSD2008-00040), the Catalan Government (SGR 2009-458) and the Estonian Ministry of Education and Science (SF1090065s07) and the join collaborative project between Spanish CSIC and the Estonian Academy of Sciences.

\section{References}

Ashton IW, Hyatt LA, Howe KM, Gurevitch J, Lerdau MT (2005) Invasive species accelerate decomposition and litter nitrogen loss in a mixed deciduous forest. Ecological Applications, 15, 1262-1272.

Baruch Z, Goldstein G (1999) Leaf construction cost, nutrient concentration, and net $\mathrm{CO}_{2}$ assimilation of native and invasive species in Hawai'i. Oecologia, 121, 183-192.

Blomberg SP, Garland TJ, Ives AR (2003) Testing for phylogenetic signal in comparative data: behavioral traits are more labile. Evolution, 57, 717-745.

Blumenthal D, Mitchell CE, Pysek P, Jarosik V (2009) Synergy between pathogen release and resource availability in plant invasion. Proceedings of the National Academy of Sciences USA, 106, 7899-7904.

Brewer JS, Cralle SP (2003) Phosphorus addition reduces invasion of a longleaf pine savanna (Southeastern USA) by a non-indigenous grass (Imperata cylindrica). Plant Ecology, 187, 237-245.

Cao G, Giambelluca TW, Stevens DE, Schroeder TA (2007) Inversion variability in the Hawaiian trade wind regime. Journal of Climate, $\mathbf{2 0}$ 1145-1160.

Cassidy T, Fownes JH, Harrington RA (2004) Nitrogen limits an invasive perennial shrub in forest understory. Biological Invasions, 6, 113-121.

Chytry M, Maskell LC, Pino J, Pysek P, Vilà M, Font X, Smart SM (2008) Habitat invasions by alien plants: a quantitative comparison among Mediterranean, subcontinental and oceanic regions of Europe. Journal of Applied Ecology, 45, 448-458.

Daehler CC, Baker R (2006) Part 1: articles. In: Records of the Hawaii Biological Survey for 2004-2005. Bishop Museum occasional papers, 87 (eds Evenhuis NL, Eldredge LG), pp. 3-18. Bishop Museum, Honolulu.

Daehler CC, Denslow JS, Ansari S, Kuo HF (2004) A risk assessment system for screening out invasive pest plants from Hawai'i and other Pacific Islands. Conservation Biology, 18, 360-368.

Dassonville N, Vanderhoeven S, Gruber W, Meerts P (2007) Invasion by Fallopia japonica increases topsoil mineral nutrient concentrations. Ecoscience, 14, 230-240.

Dassonville N, Vanderhoeven S, Vanparys V, Heyez M, Gruber W, Meerts $P$ (2008) Impacts of alien invasive plants on soil nutrients are correlated with initial site conditions in NW Europe. Oecologia, 157, 131-140.

Deenik J, McClellan AT (2007) Soils of Hawai'i. Soil and Crop Management, SCM-20. College of Tropical Agriculture and Human Resources, University of Hawai'i at Manoa, Honolulu.

Dunbar-Co S, Sporck MJ, Sack L (2009) Leaf trait diversification and design in seven rare taxa of the Hawaiian Plantago radiation. International Journal of Plant Science, 170, 61-75.
Ehrenfeld JG (2003) Effects of exotic plant invasions on soil nutrient cycling processes. Ecosystems, 6, 503-523.

Feng YL, Lei YB, Wang RF et al. (2009) Evolutionary tradeoff for nitrogen allocation to photosynthesis versus cell walls in an invasive plant. Proceedings of the National Academy of Sciences USA, 106, 1853-1856.

Foote DE, Hill EL, Nakamura S, Stephens FE (1972) Soil Survey of Islands of Kauai, Oahu, Maui, Molokai, and Lanai, State of Hawaii, United States Department of Agriculture Soil Conservation Service with The University of Hawaii Agricultural Experiment Station, Honolulu.

Funk JL, Vitousek PM (2007) Resource-use efficiency and plant invasion in low-resource systems. Nature, 446, 1079-1081.

Garland TJ, Harvey PH, Ives AR (1993) Procedures for the analysis of comparative data using phylogenetically independent contrast. Systematics Biology, 41, 18-32.

Giambelluca TW, Nullet MA, Schroeder TA (1986) Rainfall Atlas of Hawai'i. Hawa'i Division of Water and Land Development, Department of Land and Natural Resources, Honolulu.

Guillou H, Sinton J, Laj C, Kissel C, Szeremeta N (2000) New K-Ar ages of shield lavas from Waianae Volcano, Oahu, Hawaiian Archipielago. Journal of Volcanology and Geothermal Research, 96, 229-242.

Holmgren M, Aviles R, Sierralta L, Segura A, Fuentes ER (2000) Why have European herbs so successfully invaded the Chilean matorral? Effects of herbivory, soil nutrients, and fire. Journal of Arid Environment, 44, 197-211.

Howard TG, Gurevich J, Hyatt L, Carreiro M, Lerdau M (2004) Forest invasibility in communities in southern New York. Biological Invasions, 6, 393-410.

Hughes RF, Denslow JS (2005) Invasion by a $\mathrm{N}_{2}$-fixing tree alters function and structure in wet lowland forest of Hawaii. Ecological Applications, 15, 1615-1628.

Hughes RF, Uowolo A (2006) Impacts of Falcataria moluccana invasion on decomposition in Hawaiian lowland wet forest: the importance of stand-level controls. Ecosystems, 9, 977-991.

Kull O, Niinemets Ü (1998) Distribution of leaf photosynthetic properties in tree canopies: comparison of species with different shade tolerance. Functional Ecology, 12, 472-479.

Kurten EL, Synder CP, Iwata T, Vitousek PM (2008) Morella cerifera invasion and nitrogen cycling on a lowland Hawaiian lava flow. Biological Invasions, 10, 19-24.

Larcher W (1963) Die Eignung abgeschnittener Zweige und Blätter zur Bestimmung des Assimilationsvermögens. Planta, 60, 1-18.

Lavin SR, Karasov WH, Ives AR, Middleton KM, Garland TJ (2008) Morphometrics of the avian small intestine compared with that of nonflying mammals: a phylogenetic approach. Physiological and Biochemical Zoology, 81, 526-550.

Leishman MR, Haslehurst T, Ares A, Baruch Z (2007) Leaf trait relationships of native and invasive plants: community- and global-scale comparisons. New Phytologist, 176, 635-643.

Ludlow AE (1991) Ochna pulchra Hook: leaf growth and development related to photosynthetic activity. Journal of Experimental Botany, 68, 527-540.

Maddison WP, Maddison DR (2009) Mesquite: a modular system for evolutionary analysis. Version 2.6. Available at http://mesquiteproject.org (accessed April 2009).

Mooney HA, Hobbs RJ (2000) Invasive Species in a Changing World. Island Press, Washington, USA.

Müller-Dombois D, Fosberg FR (1998) Vegetation of the Tropical Pacific Islands. Springer Verlag, New York.

Niinemets Ü, Valladares F, Ceulemans R (2003) Leaf-level phenotypic variability and plasticity of invasive Rhododendron ponticum and noninvasive Ilex aquifolium co-occurring at two contrasting European sites. Plant, Cell and Environment, 26, 941-956.

Niinemets Ü, Wright IJ, Evans JR (2009) Leaf mesophyll diffusion conductance in 35 Australian sclerophylls covering a broad range of 
foliage structural and physiological variation. Journal of Experimental Botany, 60, 2433-2449.

Ostertag R, Verville JH (2002) Fertilization with nitrogen and phosphorus increases abundance of non-native species in Hawaiian montane forest. Plant Ecology, 162, 77-90.

Peñuelas J, Sardans J, Ogaya R, Estiarte M (2008) Nutrient stoichiometric relations and biogeochemical niche in coexisting plant species: effect of simulated climate change. Polish Journal of Ecology, 56, 613-622.

Pheloung PC, Williams PA, Halloy SRP (1999) A weed risk assessment model for use as a biosecurity tool evaluating plant introductions. Journal of Environmental Management, 57, 239-251.

Porder S, Asner GP, Vitousek PM (2005) Ground-based and remotely sensed nutrient availability across a tropical landscape. Proceedings of the National Academy of Sciences USA, 102, 10909-10912.

Reich PB, Walters MB, Ellsworth DS (1997) From tropics to Tundra: global convergence in plant functioning. Proceedings of the National Academy of Sciences USA, 94, 13730-13734.

Sala A, Verdaguer D, Vilà M (2007) Sensitivity of the invasive geophyte Oxalis pes-caprae to nutrient availability and competition. Annals of Botany, 99, 637-645.

Sardans J, Peñuelas J (2007) Drought changes the dynamics of trace element accumulation in a Mediterranean Quercus ilex forest. Environmental Pollution, 147, 567-583.

Schuur EAG, Matson PA (2001) Net primary productivity and nutrient cycling across a mesic to wet precipitation gradient in Hawaiian montane forest. Oecologia, 128, 431-442.

Scowcroft PG, Turner DR, Vitousek PM (2000) Decomposition of Metrosideros polymorpha leaf litter along elevational gradients in Hawaii. Global Change Biology, 6, 73-85.

Siemann E, Rogers WE (2007) The role of soil resources in an exotic tree invasion in Texas coastal prairie. Journal of Ecology, 95, 689-697.

Thomson V, Leishman MR (2005) Post-fire vegetation dynamics in nutrient-enriched and non-enriched sclerophyll woodland. Australian Ecology, 30, 250-260.
Uehara G, Ikawa H (2000) Use of Information from Soil Surveys and Classification. Plant Nutrient Management in Hawaii's Soils, Approaches for Tropical and Subtropical Agriculture. College of Tropical Agriculture and Human Resources, University of Hawai'i at Manoa, Honolulu.

Vitousek PM, Walker R (1989) Biological invasion by Myrica faya in Hawai'i: plant demography, nitrogen fixation, ecosystem effects. Ecological Monographs, 59, 247-265.

Wagner LR, Herbst DR, Sahmer SH (1999) The Manual of Flowering Plants of Hawai'I, revised edn. University of Hawai'i Press, Honolulu, Hawai í.

Webb CO, Donoghue MJ (2005) Phylomatic: tree assembly for applied phylogenetics. Molecular Ecology Notes, 5, 181-183.

Witkowski ETF (1994) Growth of seedlings of the invasives, Acacia saligna and Acacia cyclops, in relation to soil-phosphorus. Austral Journal of Ecology, 19, 290-296.

Wright IJ, Reich PB, Westoby Met al. (2004) The worldwide leaf economics spectrum. Nature, 428, 821-827.

\section{Supporting Information}

Additional Supporting Information may be found in the online version of this article:

Table S1. Mean and SE $(n=3)$ for each physiological, structural and chemical variable studied in each one of the species studied.

Please note: Wiley-Blackwell are not responsible for the content or functionality of any supporting materials supplied by the authors. Any queries (other than missing material) should be directed to the corresponding author for the article. 